\title{
Animal Rights: A Philosophical Evaluation
}

\author{
Innocent Sanga, PhD \\ ORCID: https://orcid.org/0000-0002-3397-6937 \\ Department of Philosophy and Ethics \\ Saint Augustine University of Tanzania
}

Corresponding Mail: innocentsangamby@gmail.com

\begin{abstract}
Copyright resides with the author(s) in terms of the Creative Commons Attribution CC BY-NC 4.0. The users may copy, distribute, transmit and adapt the work, but must recognize the author(s) and the East African Journal of Education and Social Sciences
\end{abstract}

\begin{abstract}
Animal right is one of the most controversial issues in the contemporary world. A number of scholars have been discussing on whether the animals have rights like human beings or not. Through this debate, their opinions can be put into three groups; those who deny animal moral status, those who give some moral considerations to animals but deny them a fuller moral status, and those who extend rights to animals. This paper then gives a general overview on 'Do Animals have Rights?' It gives the meaning of the term "right" and explains whether the term right applies to animals too. It also portrays a drama whereby animals complain against sufferings imposed on them by human beings and a response given by a human being. It is also followed by philosophical debate on animal rights: pro and cons arguments. The Christian perspective is not left out. Finally, the paper ends with critical evaluations and conclusion. In evaluation of the debate on animal rights, the study found that, animals deserve to be treated well based on the argument that they have rights as animals. The main recommendation is that human beings should change their perception concerning animals by respecting animal.
\end{abstract}

Keywords: Animal rights; philosophy; science; ethics, Law; environment

How to cite: Sanga, I. (2021). Animal Rights: A Philosophical Evaluation. East African Journal of Education and Social Sciences 2(4), 111-124. Doi: https://doi.org/10.46606/eajess2021v02i04.0135.

\section{Introduction}

Right is a justifiable claim to have or to obtain to which one is entitled. It can also be defined as a justifiable claim to act in a particular manner if one is entitled to do so. A right may be moral or legal. Moral right is a justifiable claim on moral grounds to have anything or to act in a particular manner. For example, a beggar has a moral right to receive alms but cannot take any legal action in case the other people refuse to assist him. A legal right is one which is conferred by law and it is enforced by legal procedures (EXP NMC EXP, 2003). Some rights are natural and basic for human existence. These are known as fundamental human rights. For example, right to life and right to eat. Fagothey (1959) states that the word 'right' squares to a norm of morality. It is the ethical concept of oughtness; how I ought to act and how others ought to act towards me. Thus, right has a universal meaning: it applies to all people, not just to a few.

The term 'animal' in this paper implies an irrational being that experiences pain and pleasure. Examples of animals are dogs, elephants, lions, cats, apes, rabbits, crocodiles and cows (Robert, 1999). The concept of Animal rights explains that certain things are wrong as a matter of principle, that there are some things that it is morally wrong to do to animals. Human beings should not do those things, no matter what the cost to humanity for not doing them. Human beings must not do those things, even if they do them in a humane way. For example, if animals have a right not to be bred and killed for food, then animals must not be bred and killed for food. It makes no sense if animals are given 5-star 
treatment throughout their lives and then killed humanely without any fear or pain - it's just plainly wrong, in principle, and nothing can make it right (BBC, 2021).

Narveson (1986) argued that animals do not have rights simply because they do not have a capacity to reason. In addition, some scientists are against animal rights because animals are needed for experimentation (Gannon, 2007). On the contrary, there are scholars like Bernard Rollin who support the idea of animal rights. He argues that mere experimentation of animals totally ignores the rational ethical basis for elevating legal protection for animals (Rollin, 2011). Regan (2004) are among scholars who argue for animal rights based on the idea that animals feel pain and sorrows just like human beings.

One question to ponder is, do animals have rights or not? Why do some animals portray some human qualities? For instance, dogs have a capacity of driving car (Hamblin, 2013) others have a capacity of identifying the drug dealers and even terrorist. How is it possible to send some dogs to go to the shops and buy some goods just like human beings? Should we say single handedly that only human beings have the faculty of reason when the animals can take care of a human baby in the forest to a point that it is fully grown? In Kenya, how can it be said to "Mkombozi" dog that rescued the baby who was dumped? Some animals are very conscious as regards time for meals than a human being (for example our cats at priestly dinning -CUEA...they knew our time table.....chicken day, beans day. They only appeared in a chicken day, they did not appear on beans day. Priests could fail to follow the exact time table...but cats could.

The big question today is: "do animals have rights?" Animals and human beings have some similarities but at what point do we say some are at the level of instinct and some are at the level of reason? Who is a human being and what is an animal? In any case can a human being do anything to the animal just because he thinks he has the right, right to do anything? Who has given this right to a human being? Equally we can ask 'do animals have duty and obligation? Do they have self-consciousness? Are they aware of their self-awareness? What is the role of philosophy in this ground?

This paper will help to shade more light concerning why should people treat animals in a good and reasonable way. While some people mistreat animals as if they are senseless like stones, this work will contribute towards formation of good character in human beings to treat animals in a good manner. The method used in this work is analytic inductive and synthetic deductive. This method functions in the way that the individual phenomenon is examined to find out the observable phenomena for the sake of generating principles. Once this is done, principles generated are synthesized to be applied to the individual phenomena as a whole (Lombo \& Russo, 2014). This method suits this work because animals have observable characteristics manifesting possession of rights. It is from such characteristics where rights are to be generated and be applied to animals.

\section{Discussions \\ A Cry of Animals}

The animals complain that each time the good relationship that has been co existing between them and human beings deteriorates day after day. An imaginary cry of animals can be described as follows: "A human being is no longer a friend, following the brutal actions he imposes on us" (Animal Kingdom, 2021). "Back to history, a human being used to be close to us; we lived together in a common house and play ground. Now days he claims to have rights which we do not have. He uses us in different ways in order to save his or her life." When Christmas season approaches, we, animals, are not at ease because most us will be slaughtered to maximize the joy and happiness of human beings. Are we not part of this salvation brought by Jesus? Why only for human beings? We are all creatures created by the same creator (Onye, 2011).

In the contemporary society, there are many ways in which animals are subjected to suffering; animal experimentation, intensive farming, horse and dogs racing, pet ownership, zoos, the use of animals in teaching as teaching aids (Coghlan, 2021). From such practices, it is understood that the benefit to humans clearly outweighs the pain and suffering experienced by animals (Baumans, 2004). Bernard Rollin in his book, 'Animal Rights and Morality' gives some unnecessary reasons which lead people to kill animals abusively. He states that People kill animals because they are going on vacation. People kill animals because they are moving to a place where it will be difficult to keep an animal or where animals are not allowed, people kill animals because their daughter is going away to college and cannot take care of it, people kill animals because they are getting divorced or separated and cannot agree who 
will keep the animal...people kill animals because they cannot housebreak them or train them not to jump up on the furniture ...people kill animals because they are getting old and cannot jog with them, people kill animals because they feel themselves getting old and are afraid of dying before the animal, people kill animals because they need a new one (Rollin, 2011).This citation shows how people abuse animals unreasonably. It is from this ground that the international community has to take ethical initiatives which can safeguard animals. In case of human utility, greater reasons should be outlined to justify the human needs.

\section{The Defense of a Human Being}

In defense, human beings claim that they have rights just because is God given. First, human beings think that they have the capacity of moral law which binds and are capable of grasping the binding character. Due to the faculty which God Himself has granted them, they are able to respect the rights that human beings possess. Second, they claim that they have been created in the image of God, with a will which is free and God has given them the power to recognize unlike other creatures. Therefore, a human being is able to differentiate good and evil unlike animals (Rollin, 2011) In this ground, a human being justifies that he is the only one who deserves rights and is radically different from other creatures. Furthermore, he has a power to dominate and use other creatures to preserve his life.

\section{The Philosophical Debate on Animal Rights The Arguments against Animal Rights}

The debate on animal rights has attracted the attention of many scholars. In this section we shall examine various views of different scholars. St Augustine states that God created human beings in his own image, entrusted him with will, rationality, freedom and power to recognize what is good and wrong, unlike other creatures. Hence, animals have no rights at all (Boss, 1999). St. Thomas Aquinas, argued that only beings that are rational and capable of determining their actions are the only beings toward which we should extend concern for their own sake. Moreover, our moral law is binding as humans have the power given by God to grasp its binding character and must therefore respect the rights that humans possess. Hence, animals have no rights. Cartesian theories state that animals are not conscious and therefore have no interests or wellbeing to take into consideration when discussing the effect of our actions. Therefore, we cannot claim that they have rights as human beings. Rights only apply to beings that are capable of thought, capable of defining rights and creating an organized means of government for protecting such rights (Dombrowski, 1988).

According to Kant, a human being does not have direct duties to animals; he has duties to humans who are self-conscious and rational. Animals do not have will, therefore, they cannot have good will at all. Thus they do not have intrinsic value. Roger Scruton takes the position of Kant that animals are not members of the moral community because they are not rational and self-conscious (White, 2009). Cohen and Regan (2001) states that, regarding moral responsibility, animals are totally amoral; there is no morality for them; they do no wrong. On this ground he quoted a contemporary philosopher, Regan who calls animals 'moral patients' that they neither do wrong nor good, even when the moral patient has caused a great harm to another, the moral patient has not done wrong, only moral agents (human being) can do what is wrong. All in all, the above opponents of animal rights deny animal moral status or equal consideration with humans due to lack of self-consciousness.

\section{The Arguments for Animal Rights}

Some scholars sympathize and strictly defend animal rights. For instance, Buddhists and Hinduists give a justifiable ground on the animal rights basing on the ahimsa principle that meat eating contributes to harming and mental violence of a human being. It is through ahimsa principle that Gandhi influenced the American civil rights and activists. They state that all living beings are interconnected. That means, we have to extend moral respect to all living beings for the world to be peaceful (McLaughlin, 2012). Hence, the violence and conflicts in the world is caused by the mistreatment which human beings are subjecting to animals. Tom Regan and other few philosophers like Peter Singer strongly oppose the behavior of people to use animals as a source of food as tools for scientific experiments and as house pets (Regan \& Singer, 1989). The feminists' philosophers are divided on the issue of animal rights; people like Carol Adams, strongly promote animal rights arguing that 'domination of women and domination of animals are part of the patriarchal prototype. Women can only achieve their autonomy by rejecting the cultures which allow people to subordinate other animals (Voydatch, 2017). 
Vegetarian movement maintains that animals have moral values. They point out various forms which people subject animals to suffering in the contemporary world. Such forms are genetic engineering, animal experimentation and commercial product, among others. Hence, they say, in order to reduce these sufferings subjected to animals, people should sacrifice some wrong acts against animals, such as meat eating, wearing leather or fur, animal experiments, intensive animal farming and raising animals indoors (Detmer, 2007).

Environmentalists argue that animal farming destructs the natural environment and the solution is to eliminate animal agriculture. Reformists and the Abolitionists totally oppose animal experimentation, stating that even if it has a great value to human beings, they cannot justify the use of animals to develop human interests. Peter Singer attributes moral standing to some animals such as mammals and he states that it is wrong to subject sufferings to them (McLaughlin, 2012).

Warren states that animals have rights but they are weaker than human rights, having weaker rights does not give room to make animals suffer or to kill them without reason. Regan argues that animals have an inherent value which demands right. He says those animals with inherent value have rights (White, 2009). Moral equality theories extend the concept of rights to animals on the ground that they have similar physiological and mental capacities as infants or disabled human beings. The supporters of this argument are philosophers who argue that right is not only applied to human beings but also to animals (Nobis, 2016).

\section{Christian View}

The Christian perspective is very complex because of the different Christian communities in the world. While these come up with different views regarding animal rights, majority of Christian communities hold that animals should be treated humanely (Austin, 2015). Jesus' appreciation for animals is demonstrated by the repeated analogies and references to animals in his teachings. He referred to his followers and those who worship God as sheep, and he compared God's care for Jerusalem with a hen's concern for her brood. In his teachings, Jesus compared himself to such animals as the lamb and the dove, known for their innocence, meekness and docility (Regenstein, 2006). He often represented animals as being under God's providence (The New Jerusalem Bible, Luke 13:15, 14:5). Some Christian philosophers have stated that we should emulate the example of Jesus and other Saints like St Francis of Assisi, on how to treat animals, with compassion as well as to demonstrate the respectful stewardship of humanity (Regenstein, 2006). In the book of Deuteronomy, the bible forbids cruelty to animal (The New Jerusalem Bible, Deuteronomy, 25.5.). On the contrary, other Christians state that animals are to be a means to an end; they should be freely used as a commercial product which people utilize in order to serve humanity's desire (Regenstein, 2006).

The Catechism of the Catholic Church takes the position that a Christian is called to express kindness to the world's creatures. In general, people have moral obligations to avoid causing unnecessary suffering to animals. Meat eating in the context of nourishment is morally permitted. (The New Jerusalem Bible, Leviticus 11) whereas in the biblical point of view; God created a human being in his own image and gave a general dominion over other beings of the earth. The book of Proverbs states that a righteous man cares about his animal's health. (The New Jerusalem Bible, proverbs 12: 10). In the New Testament, we see Jesus associate himself with his disciples with an act of fishing (The New Jerusalem Bible, John 21.). The act of fishing implies the support of animal eating. On the other hand, Jesus refers to himself as a good shepherd; this act implies the larger context of animal rights as the good shepherd lays down his life for his sheep (The New Jerusalem Bible, John 10: 11).

\section{Evaluation of the debate}

We can vividly come up with our general evaluation that the above opinions can be categorized into three ways. The first category is indirect theories: These are for the ones who deny animal moral status or equal consideration with humans due to lack of consciousness, reason or autonomy. They ultimately deny moral status to animals. The second category is direct or unequal theories. These are the ones who give some moral considerations to animals, but deny them a fuller moral status due to their inability to respect other agent's right or display reciprocity with a community of equal agents. The third category is moral equality theories. These are the ones who extend the concept of rights to animals on the ground that they have similar physiological and mental capacities as infants or disabled human beings. The questions would be, should a human being be permitted to subject animals for experimentation, genetic engineering and commercial product? At which 
point should an animal be sacrificed for experimentation, genetic engineering, commercial product? Is it morally permissible to use animals in experiments and other activities; using ethical guideline? Another fundamental question is: is it ethically acceptable for animals to be used for serving human life? What is the relationship that should be upheld between two parties? Is it in the order of the law of nature to take away the animal rights? Or is it situational and determined by man? If there is any or there isn't any relationship given above, what could be the criterion?

\section{The Author's Arguments}

A human being has close relationship with animals. In this sense animals can be used to serve human life with precautions. First, animals should not be mistreated unnecessarily. Therefore, animals may be used if necessary, for experiments that will save the lives of human beings. This means that the interest of animals should not override the interests of human beings (Mackinnon, 2009). For example, we can conduct animal experiment for the sake of obtaining a good medical treatment for human beings (therapeutic purposes). For example in the past, there were many cases of polio vaccination, but now is completely eradicated because of animal research (Ghosh, 2021). In that case, if we stop making animal research for polio, it will endanger human beings at large. Therefore, animal experiment can be conducted in order to advance the interest of a human being. In this case, human rights override animal rights. Therefore, we can use animals for medical therapies, antibiotics, vaccines among others. If animals are used freely without ethical restrictions, animals will have been abused to a large extent. Thus, animals can be used for the good of a rational being. However, it does not mean that animals should be used unnecessarily, but they should be used for the betterment of human beings. Regarding the relationship between animals and human beings, animals should be taken care of and be protected. Thus, animals take the position of being instruments for human beings (instrumental value). That means any worth they may produce should be for the good of human beings. Fundamentally, the right of animals to live, to be protected from suffering, to live life according to their nature are basic rights that should be legally preserved.

\section{Conclusions and Recommendations}

The question whether animals have rights is a critical moral issue. It is still debatable in the contemporary society and the door for further research is open. As we have seen above, the greater reason for animal suffering is the advancement in science and technology. Many sources of animal suffering are being introduced such as genetic engineering, cloning, animal farming, animal housing, animal experiment, and animal factory, among others. In this context, there is a conflict of interest between animal welfare and advancement in science and technology. Therefore, we should be able to balance and weigh the needs and values for the betterment of a human being, whose values, in a hierarchical order of values, are higher than animals'.

Finally, humans should strike a balance when they are dealing with animals. The hierarchical order of values should be keenly considered. Due to scientific and technological advancement, the behavior of animal abuse has become much greater than animal protection. In this case, education for ethical animal guidelines should be considered and emphasized.

\section{References}

Animal Kingdom - Clip1. (2015, October 23). [Video]. YouTube. https://www.youtube.com/watch ?v=kym TLtt31Sw.

Austin, \& Flynn. (2015). Traversing the Gap between Religion and Animal Rights: Framing and Networks as a Conceptual Bridge. Journal of Animal Ethics, 5(2), 144. https://doi.org/1 0.5406/janimaleth ics.5.2.0144.

Baumans, V., (2004). Use of animals in experimental research: an ethical dilemma? Gene Therapy 11, S64-S66 https://doi.org/10.10 38/s j.gt.3302371.

BBC., Animal Rights. Www.bbc.co.uk. Retrieved December 14, 2021, from https://www.bbc.co.uk/ethics/animals/right s/rights_1.shtml.

Boss, Judith. (1999) 'Do Animals Have Rights'? In the Analyzing Moral Issues. Mayfield Publishing Company.

Coghlan, S., Webber, S., \& Carter, M. (2021). Improving ethical attitudes to animals with digital technologies: the case of apes and zoos. Ethics and Information Technology. Published. https://doi.org /10 .1007/s10676-021 096187contexthtt ps://en.wik ipedia.org/w iki/C 
hristianity_and_animal_rights\#Biblical_ conte xt (Retrieved on 19th June, 20017).

Cohen, C., \& Regan, T. (2001). The Animal Rights Debate. Rowman \& Littlefield Publishers.

Coghlan, S., Webber, S., \& Carter, M. (2021). Improving ethical attitudes to animals with digital technologies: the case of apes and zoos. Ethics and Information Technology. Published.https://doi.org/10.1007/s10676-

021 096187contexthttps://en.wik ipedia. org/ wiki/C hristianity_and_animal_rights\# Biblical_context (Retrieved on 19th June, 20017).

Detmer, D. (2007). Vegetarianism, Traditional Morality, and Moral Conservatism. Journal of Philosophical Research, 32(9999), 39-48. https://doi.org/10.5840/jpr_2007_1.

Dombrowski, Daniel. (1988) Hartshorne and the Metaphysics of Animal Rights. State University of New York Press.

EXP, NMC (August 31th, 2003). What Is A Right?. Freerepublic. Retrieved December 27th, 2017, from https://freerepublic.com/fo cus/news/ 973633/posts

Fagothey, A. (1959). Right and Reason; Ethics in Theory and Practice. Hassell Street Press.

Gannon, F. (2007). Animal rights, human wrongs? EMBO Reports, 8(6), 519-520. https://doi.org/10.1038/sj.embor.7400998.

Ghosh, P. (2021). Should animals be used in research? RESEARCH REVIEW International Journal of Multidisciplinary, 6(1), 136-139. https://doi.org/10.31305/rrijm.2021.v06.i01 .027 .

Hamblin, J. (2013, July 17). How Much Should a Dog's Ability to Drive a Car Affect Your Level-Headed Assessment of Readiness to Own a Dog? The Atlantic.http $\mathrm{s}: / /$ www.theatlantic.com/health/archive/20 12/12/how-much-should-a-dogs-ability-todrive-a-car-affect-your-level-headedassessm ent-of-readiness-to-own-a$\operatorname{dog} / 266485 /$.
Lombo, J. A., Russo, F., \& Cole, J. (2014). Philosophical Anthropology an Introduction. Midwest Theological Forum.

MacKinnon, Barbara. (2009) Ethics: Theory and Contemporary Issues. 6th Ed. The University of San Francisco.

McLaughlin, R. P. (2012). Non-Violence and Nonhumans: Foundations for Animal Welfare in the Thought of Mohandas Gandhi and Albert Schweitzer. Journal of Religious Ethics, 40(4), 678-704. https://doi.org/10. 1111/j.1 467-979 5.2012.00543.x.

Narveson, J. (1986). A case against animal rights. In M.W. Fox \& L.D. Mickley (Eds.), Advances in animal welfare science 1986/87 (pp. 191204). Washington, DC: The Humane Society of the United States.

Nobis, N. (2016). Animals and Ethics 101: Thinking Critically About Animal Rights. Open Philosophy Press.

Onye, K. N. (2011). Animal kingdom poems: Animal kingdom poems (2nd ed.). CreateSpace Independent Publishing Platform.

Regan, T. (2004). The Case for Animal Rights (First Edition, Updated with a New Preface ed.). University of California Press.

Regan, T., \& Singer, P. (1989). Animal Rights and Human Obligations (2nd ed.). Prentice Hall.

Regenstein, L. (2006) The bibles Teachings on Protecting animals and Nature, USA: ICPAN.

Robert Audi, (1999) The Cambridge Dictionary of Philosophy ( $2^{\text {nd }}$ ed.) Cambridge: Cambridge University Press.

Rollin, B. E. (2011). Animal Rights as a Mainstream Phenomenon. Animals, 1(1), 102-115 . https://doi.org/10.3390/ani1010102.

Voydatch, Bryannah. (2017). Overlapping Oppressions: Patriarchal Links between Women and Animals. 10.13140/RG.2. 2.26463.76967.

White, James. (2009) 'The Moral Status of Animals' in Contemporary Moral Issues. Thomson Wardsworth: USA. 